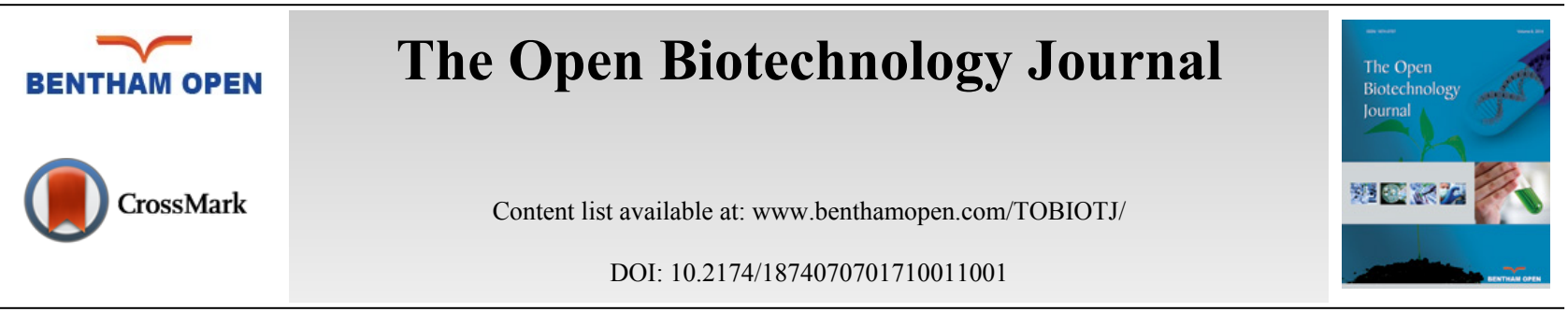

RESEARCH ARTICLE

\title{
Transformation of Antisense Chalcone Synthase (CHS) Gene into Lotus (Nelumbo Nucifera Gaertn.) by Particle Bombardment
}

\author{
Saetiew Kanjana*, Ano Prissadang*, Parinthawong Nanglak and Arunyanart Sumay \\ Department of Plant Production Technology, Faculty of Agricultural Technology, King Mongkut's Institute of \\ Technology Ladkrabang, Chalongkrung Rd., Bangkok, 10520, Thailand
}

\begin{abstract}
Chalcone synthase (CHS) is a key enzyme in the flavonoid biosynthesis pathway. $C H S$ genes were cloned from genomic DNA and cDNA from the petals of 'Buntharik' white lotus and 'Sattabangkacha' pink lotus by the PCR technique using a specific primer of the $C H S$ gene designed from the GenBank database. Semi-quantitative RT-PCR analysis revealed that the highest $C H S$ gene expression was found in the early budding stage of the pink lotus and was reduced in later stages. Shoot tips from embryos of Buntharik and Rachinee lotus were used to induce shoot clusters by cultivation on a MS medium supplemented with $40 \mu \mathrm{M}$ NAA and $0.5 \mu \mathrm{M}$ TDZ for 8 weeks and a MS medium supplemented with $50 \mu \mathrm{M}$ BA for 8 weeks. An antisense CHS gene (450 bp) from the cDNA of Buntharik lotus was used to construct a plant transformation vector; pCAMBIA1302CHSA. The vector construct was transformed into Buntharik and Rachinee shoot clusters by particle bombardment. After transformant selection and regeneration, two transformants of Buntharik shoot clusters showed GFP green spots and existence of the GFP gene and $h p t$ II gene in the genomic DNA amplified by the PCR technique. In the Rachinee transformants, 3 of 5 showed the GFP green spots and the GFP and $h p t I I$ genes were identified in amplification by PCR. After CHS gene expression analyses by semi-quantitative RT-PCR, two transformed Rachinee shoot clusters had a reduction in $C H S$ gene expression.
\end{abstract}

Keywords: Nelumbo, Gene Transfer, Particle Bombardment, CHS genes, Transformation, Lotus.

\section{INTRODUCTION}

Lotus (Nelumbo nucifera Gaertn.) is an aquatic plant of ornamental importance in Thailand. Its flowers are closely associated with Buddhism, in which it is used as a religious symbol and for decorative purposes. There are only four commercial varieties of lotus in Thailand and even though some variants have been produced through mutation induction using X-rays, gamma rays, and chemical mutagens, this approach has been unable to target specific characteristics [1]. In particular, we are interested in obtaining a variation in the flower color, which is limited to white and pink in Thai varieties.

The development of an embrygenesis protocol for lotus has been reported in bud explant culture with the bset results obtained on MS medium containing $4 \mu \mathrm{M}$ 2,4-D and $1 \mu \mathrm{M}$ BA. In this case, when calli were transferred to MS medium with $2 \mu \mathrm{M} 2,4-\mathrm{D}$ and $0.5 \mu \mathrm{M}$ BA, somatic embryos were produced [2] and an apical bud from an embryo formed an embryogenic callus when cultured on MS medium supplemented with $40 \mu \mathrm{M}$ NAA and $0.5 \mu \mathrm{M}$ TDZ for 8 weeks. The highest number of shoots was achieved in a medium supplemented with $50 \mu \mathrm{M}$ BA after 8 weeks [1].

Flower pigmentation is caused by the accumulation of pigments within the epidermal cells, including flavonoids, carotenoids and betacyanins [3]. The chalcone synthase (CHS) gene is required for biosynthesis of anthocyanin pigments that give color to various plant tissues, such as the flower and seed coat [4]. It is the key enzyme in flavonoid biosynthesis and catalyzes the condensation of one molecule of 4-coumaroyl-CoA with three molecules of malonyl-coA

\footnotetext{
* Address correspondence to these authors at the Department of Plant Production Technology, Faculty of Agricultural Technology, King Mongkut's Institute of Technology Ladkrabang, Chalongkrung Rd., Bangkok, 10520, Thailand; Tel: +66866121940; E-mails: kskanjan@yahoo.com, smartdeer777@gmail.com
} 
to form naringenin chalcone, which is the essential intermediate in biosynthesis of flavonols, flavones, isoflavonoids and anthocyanins [5]. The manipulation of this enzyme opens many possibilities for metabolic engineering of this pathway, which may be of value in the generation of some useful variations in the lotus plant [6].

Most previous plant transformation systems have used a herbicide or an antibiotic as a resistance selectable marker. However, visual markers for selection have also been used as these can increase transformation efficiency by reducing the time and the number of materials used at the screening step [7, 8]. Transformants expressing reporter genes have been generated for variety of studies. The histochemical GUS ( $\beta$-glucuronidase) assay is widely used but is destructive for tissue and therefore not suitable for direct visual selection of transformed plants. The green fluorescent protein $(G F P)$ from the jellyfish was reported to function as sensitive reporter. This gene emits bright fluorescence upon excitation with ultraviolet light. This gene was evaluated as a screening marker during cotton transforming and plant regeneration and was found to be very effective [9] The formation of the fluorescent chromophore requires no exogenous substrates or cofactors and is easily detected [10].

The aim of this study was to establish the CHS gene expression in lotus flowers (cv. Buntharik and cv. Sattabangkacha) at five developmental stages and to analyse the suitability a method for transformation of the antisense $C H S$ gene into these cultivars through particle bombardment. Visual selection of GFP expression was used to identify genetic modification.

\section{MATERIALS AND METHODS}

\section{CHS Gene Expression in Lotus}

Petals were collected from five developmental stages of lotus flowers cv. Buntharik and cv. Sattabangkacha: stage 1 - flower diameter was less than $3 \mathrm{~cm}$ (B1, S1), stage 2 - flower diameter 3-5 cm. (B2, S2), stage 3 - flower diameter 5-7 cm. (B3, S3), stage 4 - flower diameter 7-10 cm. (B4, S4) and stage 5 - open flower (B5, S5). Total RNA was extracted using an Invitrop spin RNA mini kit (Stratec Molecular, Germany) for each of the five petal stages. First-strand cDNA synthesis was performed using SuperScript ${ }^{\mathrm{TM}}$ III First-a strand Synthesis System for RT-PCR (Invitrogen) with an oligo(dt) according to manufacturer's instructions. Expression of $C H S$ genes was determined by amplification of a 458 bp using the following primers5'AAGAGCTCCCGTCAAGAGACTCA3' and 5'AAGGATCCCAGAAAATTGAG TTC3'. The specific primer of CHS gene was designed from the GenBank (accession no. FJ999632) [11]. The PCR condition for the amplification of the $C H S$ gene included $94^{\circ} \mathrm{C}$ for $5 \mathrm{~min}, 35$ cycles of denaturation $\left(94^{\circ} \mathrm{C}, 45 \mathrm{sec}\right)$, annealing $\left(58^{\circ} \mathrm{C}, 45 \mathrm{sec}\right)$ and extension $\left(72^{\circ} \mathrm{C}, 45 \mathrm{sec}\right)$, and a final extension at $72^{\circ} \mathrm{C}$ for $10 \mathrm{~min}$. The PCR products were electrophoresised on a $1 \%$ TAE agarose gel to allow visible amplification of gene on ethidium bromide.

\section{Explants and Plant Regeneration}

Seeds of lotus ( $N$. nucifera Gaertn.) cv. Buntharik and cv. Rachinee were washed thoroughly under running water for $60 \mathrm{~min}$, rinsed in 70\% ethanol for $1 \mathrm{~min}$, surface sterilized in 3\% (v/v) NaOCl (50\% Clorox plus two drops of Tween 20) for $20 \mathrm{~min}$ and rinsed three times in sterile distilled water [1]. Callus was initiated by culturing apical buds from embryos on Murashige and Skoog (MS) [12] medium containing $40 \mu \mathrm{M}$ NAA and $0.5 \mu \mathrm{M}$ TDZ for 8 weeks and callus was cultured on MS medium supplemented with $50 \mu \mathrm{M}$ BA for 12 weeks to induce shoot clusters.

\section{Plant and Plasmid Transformation}

Shoot clusters were transferred to an osmotic medium (MS medium containing $2 \mathrm{M}$ mannital and 2 sorbital) and subsequently transferred to Petri dishes $(9 \mathrm{~cm})$ and placed in the centre of a sterile, round Whatman filter paper $(2.5 \mathrm{~cm}$ diameter). The plasmid pCAMBIA1302CHSA (Fig. 1) was used in this experiment. This plasmid contains the $C H S$ gene cloned from lotus petals, with a selectable hygromycin phosphotransferase II (HPTII) gene encoding resistance to hygromycin and a green fluorescent protein $(G F P)$ gene as a reporter gene. The shoot clusters were bombarded with plasmid DNA-coated gold particles 1100 psi at $9 \mathrm{~cm}$ target distances. Four hours after bombardment, the shoot clusters were transferred from the osmotic medium to a regeneration medium (MS medium with $50 \mu \mathrm{M}$ BA) containing $15 \mathrm{mg} / \mathrm{l}$ hygromycin for 8 weeks and subcultured every two weeks to fresh medium containing the selection agent. 


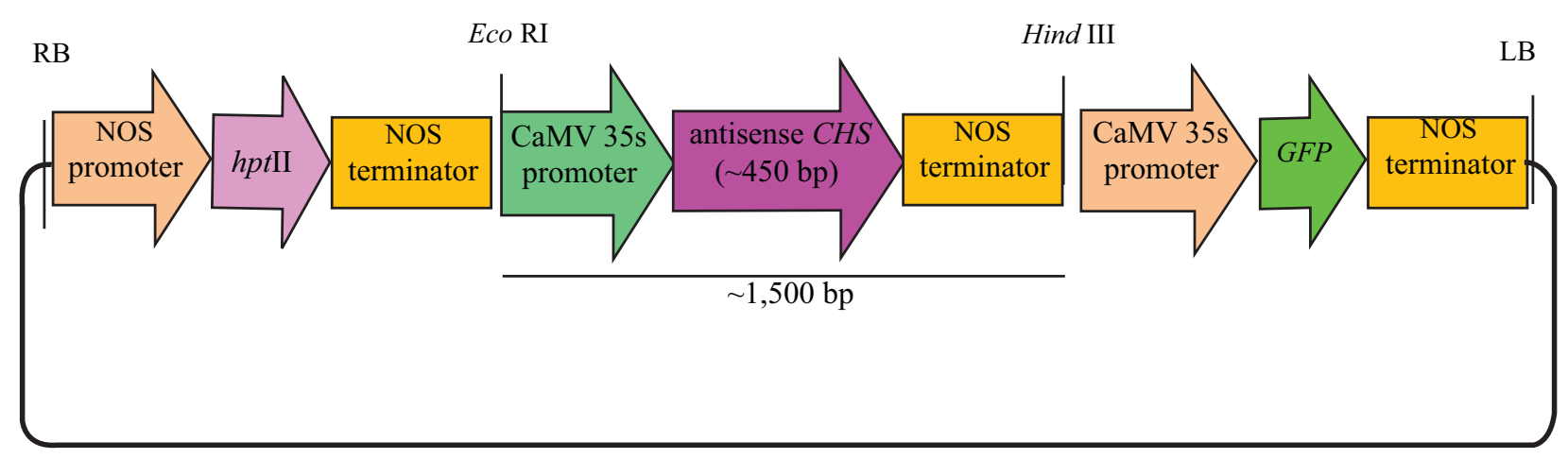

Fig. (1). pCAMBIA1302CHSA plasmid containing anti-CHS, $h p t I I$ and GFP gene.

\section{Fluorescence Microscopy}

Green fluorescence protein expression in shoot clusters of lotus was visualized under a fluorescence stereo microscope (Olympus, SZX12, USA) equipped with a $100 \mathrm{~W}$ mercury bulb light source and FITC/GFP excitation filter set with a $480 / 530 \mathrm{~nm}$.

\section{Analysis of Putative Transformed Plant}

Shoot clusters of a lotus culture on MS medium with $50 \mu \mathrm{M}$ BA and $15 \mathrm{mg} / 1$ hygromycin were putatively considered transformed. Genomic DNA was extracted from transformed and untransformed leaf tissue by using the CTAB method [13]. PCR analysis for detection of the CHS gene was done for a 458 bp fragment with primers: forward 5'AAGACTCCCGTCAAGAGACTCA3'; reverse 5'AAGGATCCCAGAAAATTGATTC3', the HPTII gene was examined for a 300 bp fragment with the primer: forward 5'ATTGACCGATTCCTTGCGGT3'; reward 5'GAGGGCGTGGATATGTCCTG3' and the GFP gene was on a 400 bp fragment with the primer: forward 5'GGAGAGGGTGAAGGTGATGC3'; reword 5'TGCCGTTCTTTTGCTTGTCG3'. The PCR reaction for amplification of the $C H S, H P T I I$ and $G F P$ gene was done at $94^{\circ} \mathrm{C}$ for $5 \mathrm{~min}, 35$ cycles of denaturation $\left(94^{\circ} \mathrm{C}, 45 \mathrm{sec}\right)$, annealing for $C H S$ and $H P T I I\left(58^{\circ} \mathrm{C}, 45 \mathrm{sec}\right) ; G F P\left(62^{\circ} \mathrm{C}, 45 \mathrm{sec}\right)$ and extension $\left(72^{\circ} \mathrm{C}, 45 \mathrm{sec}\right)$, and a final extension at $72^{\circ} \mathrm{C}$ for $10 \mathrm{~min}$. PCR products were electrophoresised on $1 \%$ TAE agarose gel and as before visible amplification of gene on ethidium bromide.

\section{RESULTS AND DISCUSSION}

\section{Gene Expression for Each Stage of Flower Development}

CHS gene expression at different stages of lotus flower development was compared by using semi-quantitative RTPCR. 18S rRNA was used as an equal-amount control of a cDNA template for PCR reactions of the CHS gene. Flower development at different stages of petal flower of lotus cv. Buntharik (B) and cv. Sattabangkacha (S) were examined. The results show that expression of the $C H S$ gene in petals of lotus cv. Sattabangkacha was higher than for lotus cv. Buntharik. The $C H S$ gene in the petals of cv. Sattabangkacha was highly expressed at stages 1 to 3 and had lower expression in stages 4-5. In cv Buntharik, however, the CHS gene was expressed at the same level in each stage. The petal color of lotus cv. Buntharik was white, while the petals of lotus cv. Sattabangkacha had a pink color at early stages and changed to white at stage 5 (Fig. 2). The expression of genes at each floral development stage can be used to predict the levels of protein and enzymes being translated by that gene. RNA was isolated from petals, with Buntharik having a white petal and Sattabangkacha having a pink petal lotus color. The pink color of Sattabangkacha was a dark pink during early flowering stages and changed to white in the last flowering stage. The results are similar to what has been reported for peony (Paeonia lactiflora) where the mechanism controlling flavonoid biosynthesis in different organs and different floral developmental stages was detected by expression levels by quantitative-PCR. For this species, nine genes (including the CHS gene) were investigated and their expression varied across the three cultivars examined [14]. Similarly, the expression pattern of $C H S$ and $C H I$ (the enzyme that catalyzes the early steps of flavonoid biosynthesis) in petals of Gentiana triflora cv. Maciry was high from stages 1 to 4 of flower development [15]. 
B1

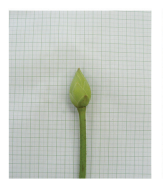

S1

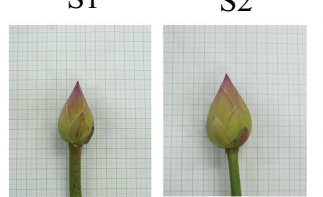

B1

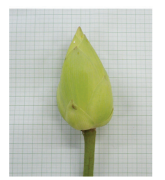

S3

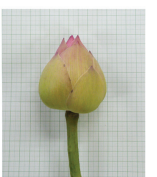

B1

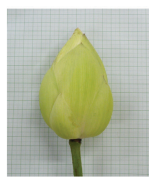

S4

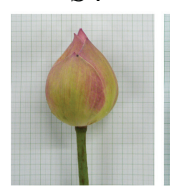

S5
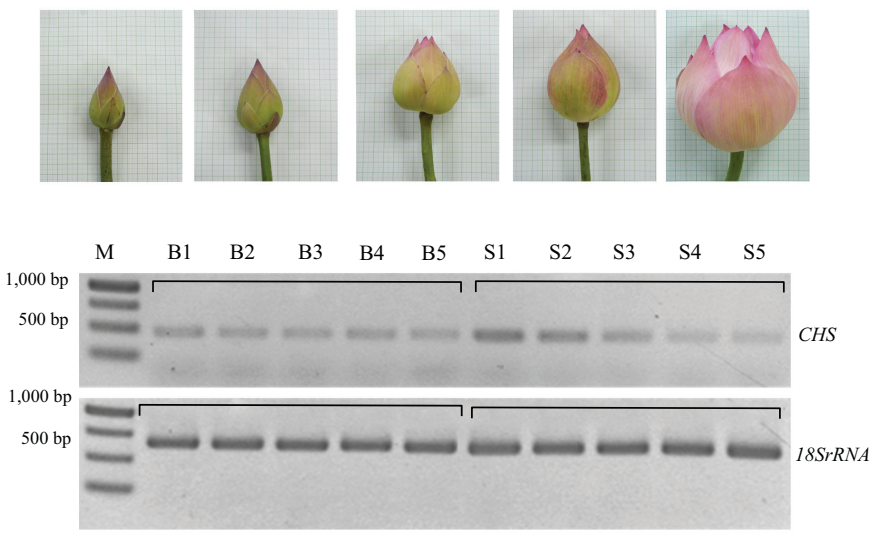

Fig. (2). Comparison of $C H S$ gene expression in each stage of flower development by Semi-quantitative RT-PCR and $18 S$ rRNA gene is control. Lotus cv. Buntharik (B) and cv. Sattabangkacha (S), flower stage 1 diameter of flower lower $3 \mathrm{~cm}$ (B1, S1), stage 2 diameter of flower 3-5 cm (B2, S2), stage 3 diameter of flower 5-7 cm (B3, S3), stage 4 diameter of flower 7-10 cm (B4, S4) and stage 5 open flower (B5, S5).

\section{Shoot Cluster Induction}

When apical buds from embryos were cultured on MS medium containing $40 \mu \mathrm{M}$ NAA and $0.5 \mu \mathrm{M}$ TDZ, there was callus growth and good formation of embryogenic callus after 8 weeks. Shoot clusters were generated from the embryogenic callus when cultured on MS medium with $50 \mu \mathrm{M}$ BA after 8 weeks (Fig. 3). The shoot clusters from these cultures were used as the target tissue for transformation. Apical buds from embryos cultured on medium containing 40 $\mu \mathrm{M}$ NAA and $0.5 \mu \mathrm{M}$ produced more embryogenic callus. Shoots were successfully produced from embryogenic callus explants using MS medium containing $50 \mu \mathrm{M}$ of BA [1]. This result confirms earlier observations in other species (e.g. Zantedeschia aethiopica) [16].

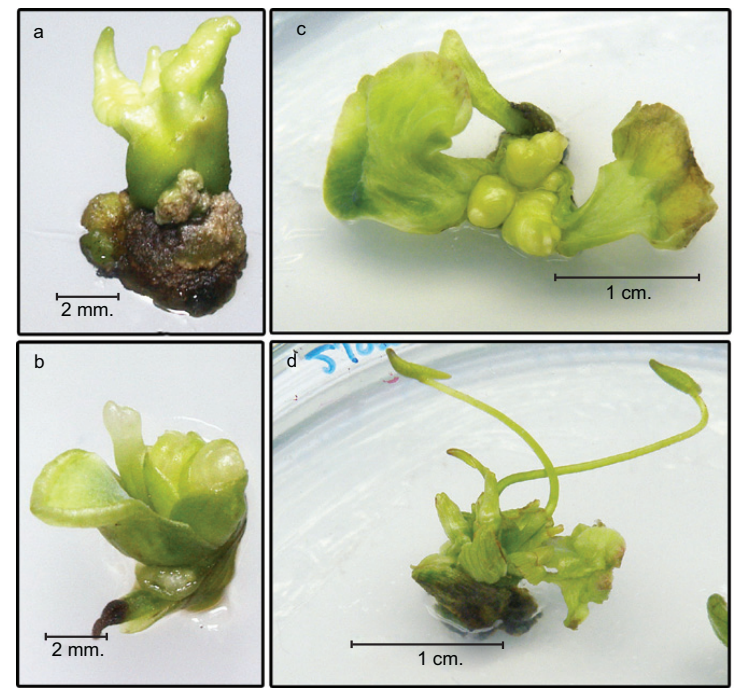

Fig. (3). Regenerating culture of $N$. nucifera Gaertn. from apical bud of embryo after 8 weeks of culture on MS medium with $40 \mu \mathrm{M}$ NAA and $0.5 \mu \mathrm{M}$ TDZ: (a) lotus cv. Buntharik; (b) lotus cv. Rachinee and change to culture on MS medium with $50 \mu \mathrm{M}$ NAA until 16 weeks; (c) cv. Buntharik; (d) cv. Rachinee. 


\section{GFP-Fluorescence in Transgenic Lotus}

The GFP gene as a reporter system was visually detected in organs and transient expression rate could be detected on shoot clusters after one week of culture. Transformed shoot clusters showed transient GFP activity in the shoot area (Fig. 4 arrow). The number of shoot clusters showing transient expression in lotus cv. Buntharik and cv. Rachinee were similar (72 and 75 pieces, respectively; Table 1). The GFP gene was also reported as a reporter gene in transgenic Phytothora palmivora and provided better visualization and was superior to GUS [17]. GFP can partially replace antibiotic selection and is particularly important when organogenesis or conversion of transformation procedures is inefficient under antibiotic or herbicide selection. It is also helpful in isolating events during the early stages of transformation [18].
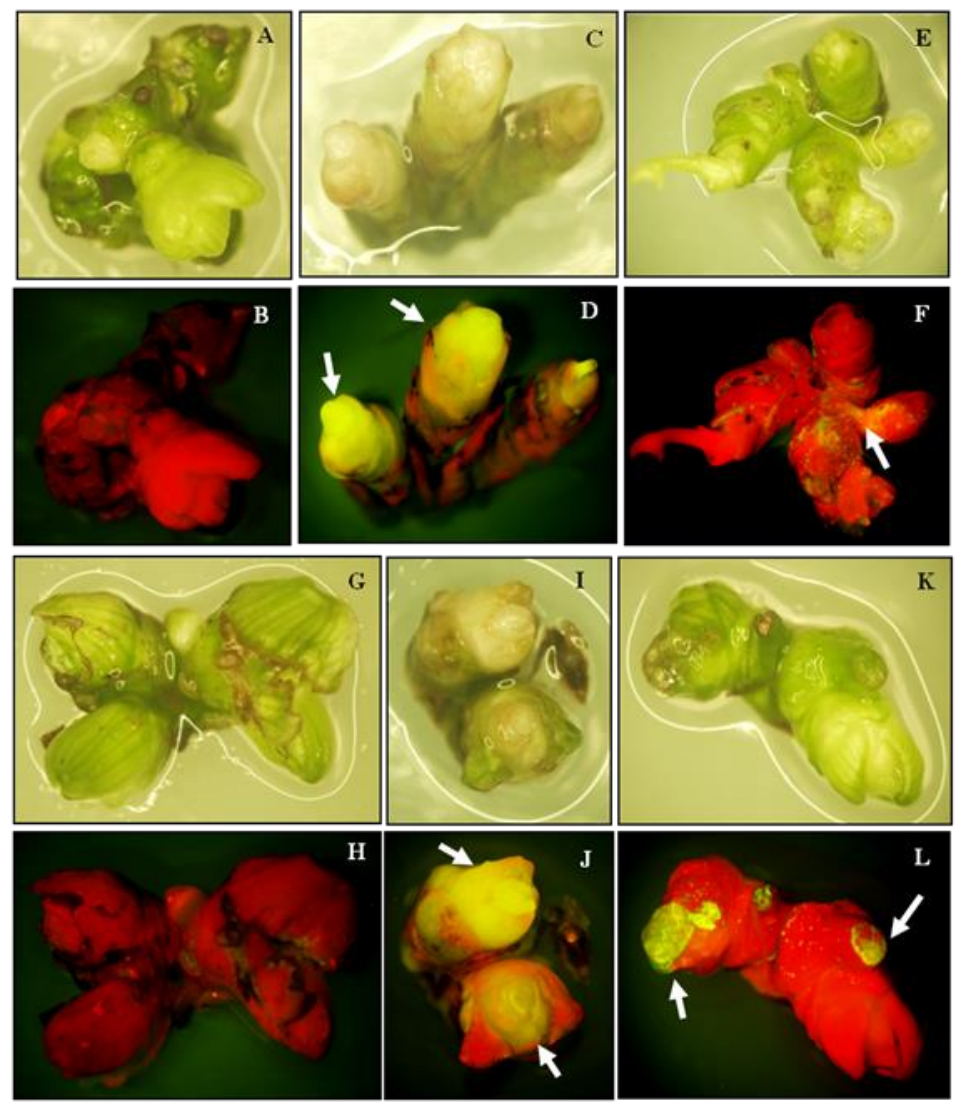

Fig. (4). Expression of GFP gene in shoot clusters lotus cv. Buntharik after transfromation 1 week (arrow). (A, B) non-transgenic shoot cluster. (C-F) transgenic shoot cluster. The upper photos use a fluorescent light and the lower photos use UV irrasiatin (7x). Shoot clusters lotus cv. Rachinee $(\mathbf{G}, \mathbf{H})$ non-transgenic shoot cluster. (I-L) transgenic shoot cluster.

Table 1. Efficiency of transformation anti-CHS gene by particle bombardment to shoot cluster of lotus cv. Buntharik and cv. Rachinee.

\begin{tabular}{|c|c|c|}
\hline & Buntharik & Rachinee \\
\hline Number of shoot clusters & 100 & 100 \\
\hline Number of shoot cluster found GFP & 72 & 75 \\
\hline Score of GFP gene expression (1-5) & $0.97 \pm 0.20$ & $0.99 \pm 0.17$ \\
\hline Percentage of number survived shoot clusters & $56.00 \pm 13.87$ & $61.00 \pm 18.51$ \\
\hline Number of shoot regeneration & 2 & 5 \\
\hline Number of GFP gene expression & 2 & 3 \\
\hline
\end{tabular}

\section{Genetic Transformation of Shoot Clusters}

Shoot clusters were transformed with pCAMBIA1302CHSA plasmid containing anti-CHS, GFP and HPTII genes. Shoot clusters were selected on selection medium. Most shoot clusters become brownish and this was sufficient to kill the untransformed shoot cluster. The number of hygromycin-resistant shoot clusters was recovered from 10-week-old shoot clusters bombarded with the plasmid. When shoot clusters were cultured on MS medium containing $50 \mu \mathrm{M}$ BA 
and $15 \mathrm{mg} / \mathrm{l}$ hygromycin for 10 weeks, the percentage of surviving shoot clusters was $56.00 \%$ (Buntharik) and $61.00 \%$ (Rachinee). Subsequently, when transferred shoot clusters were cultured on MS medium containing $50 \mu \mathrm{M}$ without hygromycin found shoots were regenerated on medium cv. Buntharik, which had only 2 shoots and cv. Rachinee, which had 5 shoots (Table 1).

Putative transformants were analyzed by PCR with a specific primer of $C H S, H P T I I$ and GFP gene. In lotus cv. Buntharik, there were three genes from two parts, the leaf and petiole. A $450 \mathrm{bp}$ fragment was identified as a $C H S$ gene, a 300 bp. fragment was identified as a HPTII gene, and a 400 bp. fragment was identified as a GFP gene (Fig. 5). The $C H S$ gene was found in all samples. Because this primer was amplify $C H S$ endogenous gene or transgene. The GFP gene was found in three samples from five respectively (Table 1 and Fig. 6).

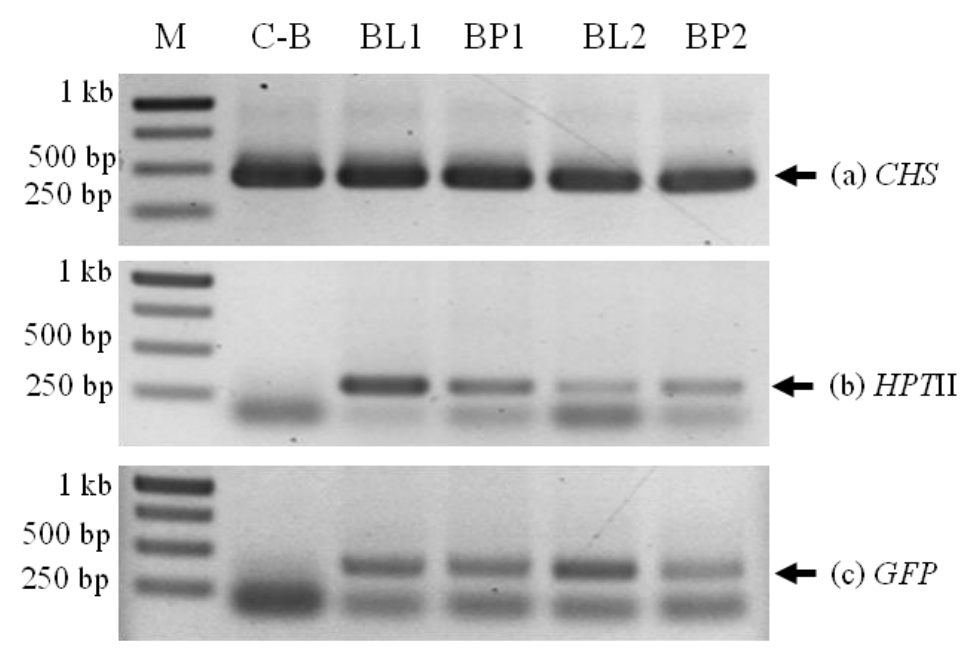

Fig. (5). PCR analysis of lotus cv. Buntharik transgenic (a) CHS gene (b) HPTII gene and (c) GFP gene. (C-B) non transgenic lotus, (BL1) leaf of transgenic, (BP1) petiole of transgenic no. 1, (BL2) leaf of transgenic no. 2, and (B5/12S) petiole of transgenic no. 2. M $=1 \mathrm{~kb}$ ladder.

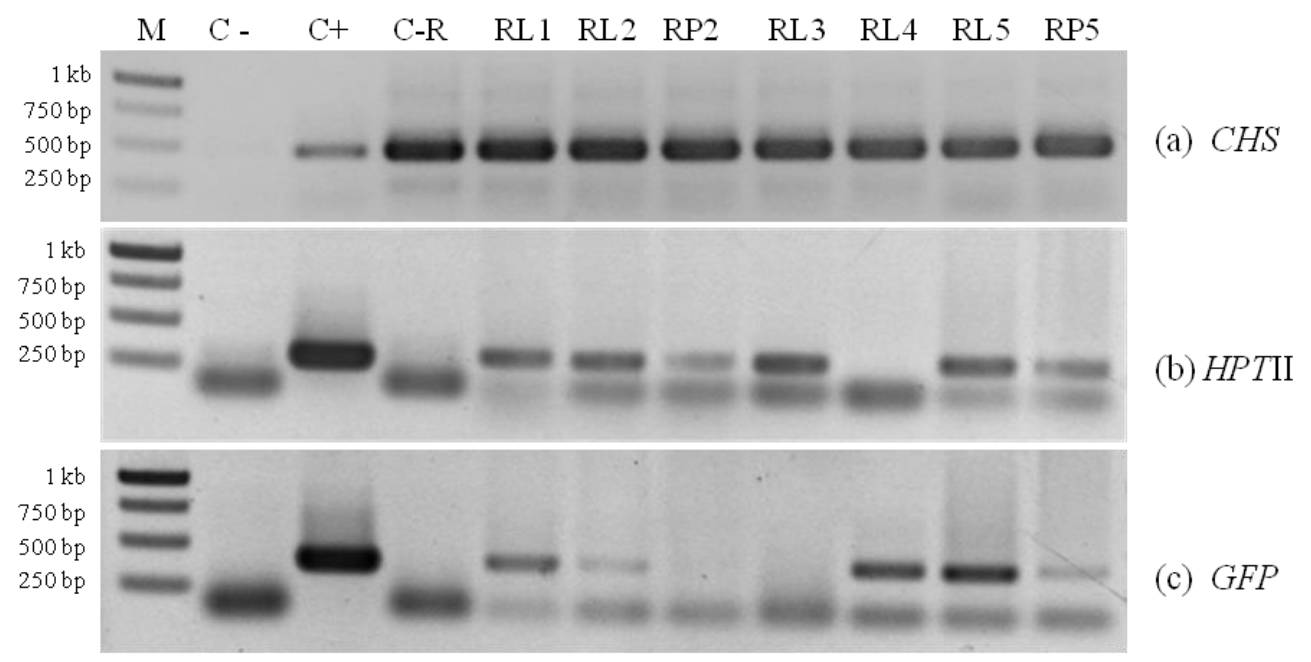

Fig. (6). PCR analysis of lotus cv. Rachinee transgenic (a) CHS gene (b) HPTII gene and (c) GFP gene. (C-R) leaf of nontransgenic, (RL1 leaf of transgenic no. 1, (RL2) leaf of transgenic no. 2, (RP2) petiole of transgenic no. 2, (RL3) leaf of transgenic no.3, (RL4) leaf of transgenic no. 4, (RL5) leaf of transgenic no. 5 and (RP5) petiole of transgenic no. 5., C d $\mathrm{H}_{2} \mathrm{O}, \mathrm{C}+$ pCAMBIA1302CHSA plasmid and $\mathrm{M}=1 \mathrm{~kb}$ ladder.

To confirm expression, semi-quantitative RT-PCR was done using a CHS gene and $18 S$ rRNA as control. CHS gene expression could be found in some samples, with decreased $C H S$ gene expression in lotus cv. Buntharik and Rachinee (Fig. 7). However, it has reported $C H S$ gene was expressed in various tissues of $N$. nucifera, with the highest expression in red flower and lowest level in the leaves [19]. 
M C-B BL1 BP1 BL2 BP2 C-R RL1 RL2 RL3 RL4 RL5

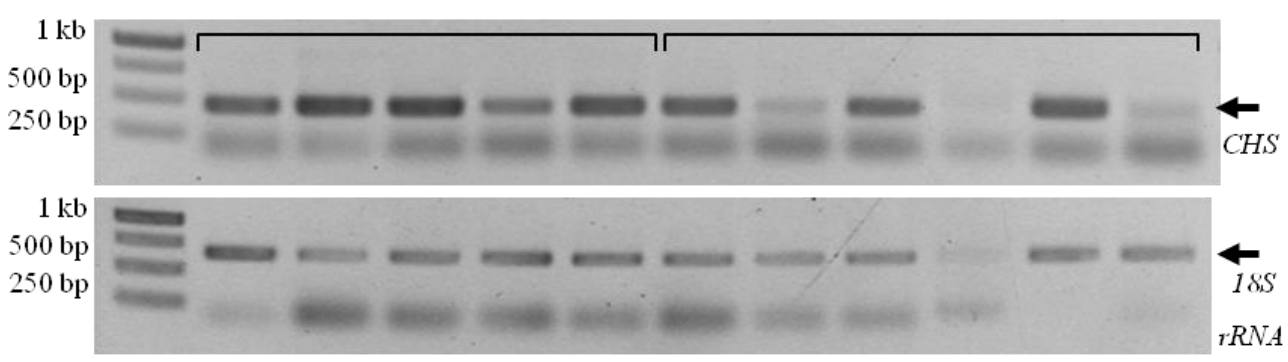

Fig. (7). Expression of CHS (458 bp) in transgenic lotus by semi-quantitative RT-PCR using $18 S$ rRNA primer (600 bp); leaf of nontrasgenic cv. Buntharik (C-B), leaf of transgenic (BL1) and petiole (BP1), leaf (BL2) and petiole of transgenic (BP2), leaf of nontrasgenic cv. Rachinee (C-R)), leaf of transgenic cv. Rachinee 1-5 (RL1-5) M=1 kb DNA marker.

In this paper, we found a high GFP transient expression rate The GFP gene was found in three samples from five respectively one-week after bombardment. Shoot clusters were selected by hygromycin. Shoots could be regenerated for only 2 and 5 shoots in Buntharik and Rachinee, respectively. Transient GFP expression was used to evaluate factors affecting transformation efficiency. With $G F P$ as a reporter marker, the growth and proliferation of an individual transgenic event could be readily tracked visually without disturbing the tissue in any way [10]. Different numbers of PCR-positive explants were achieved in the shoots of the transgenic plants. Some samples exhibited negative results for some of the genes. Some of the putative transformations were non-transgenic. Some explants also mostly likely escaped the selective medium, as observed by Kuvshinov et al. [20] and Saetiew et al. [21].

\section{CONFLICT OF INTEREST}

The authors confirm that this article content has no conflict of interest.

\section{ACKNOWLEDGEMENTS}

This research was supported by King Mongkut's Institute of Technology Ladkrabang, Bangkok, Thailand. The Centre of Excellence on Agricultural Biotechnology, Science and Technology Postgraduate Education and Research Development Office of Higher Education Commission, Ministry of Education (AG-BIO/PERDO-CHE). We thank Dr. Ian Bennett for comment and correct English that improved the manuscript.

\section{REFERENCES}

[1] Buathong R, Saetiew K, Phansiri S, Parinthawong N, Arunyanart S. Tissue culture and transformation of the antisense DFR gene into lotus (Nelumbo nucifera Gaertn.) through particle bombardment. Sci Hortic (Amsterdam) 2013; 161: 216-22. [http://dx.doi.org/10.1016/j.scienta.2013.06.040]

[2] Arunyanart S, Chaitrayagun M. Induction of somatic embryogenesis in lotus (Nelumbo nucifera Geartn.). Sci Hortic (Amsterdam) 2005; 105: 411-20.

[http://dx.doi.org/10.1016/j.scienta.2005.01.034]

[3] Grotewold JME, Koes R. How genes paints flowers and seeds. Treads Plant Sci 1998; 3: 212-7.

[4] Eckardt AN. Tissue-specific siRNAs that silence CHS genes in soybean. Plant Cell 2009; 21: 2983-4. [http://dx.doi.org/10.1105/tpc.109.072421]

[5] Napoli C, Lemieux C, Jorgensen R. Introduction of chimeric chalcone synthase gene into petunia results in reversible co-suppression of homologous genes in trans. Plant Cell 1990; 2(4): 279-89. [http://dx.doi.org/10.1105/tpc.2.4.279] [PMID: 12354959]

[6] Sun W, Meng X, Liang L, et al. Molecular and biochemical analysis of chalcone synthase from freesia hybrid in flavonoid biosynthetic pathway. PLoS One 2015; 10(3): e0119054. [http://dx.doi.org/10.1371/journal.pone.0119054] [PMID: 25742495]

[7] Hraska M, Rakousky S, Eurn V. Green fluorescent protein as a vital marker for non-destructive detection of transformation events in transgenic plants. Plant Cell Tiss Org 2006; 86: 303-18. [http://dx.doi.org/10.1007/s11240-006-9131-1]

[8] Jin SX, Zhang SL, Ling SG, Nie YC, Guo XP, Huang C. Factors affecting transformation efficiency of embryogenic callus of upland cotton (Gossypium hirsutum L.) with Agrobacterium tumefaciens. Plant Cell Tiss Org 2005; 81: 229-37. 
[http://dx.doi.org/10.1007/s11240-004-5209-9]

[9] Jin SX, Liu GZ, Zhu HG, Yang XY, Zhang XL. Transformation o upland cotton (Gossy hirsutum L.) with gfp gene as a visual marker. J Integr Agric 2012; 11(6): 910-9.

[http://dx.doi.org/10.1016/S2095-3119(12)60081-1]

[10] Santi C, Svistoonoff S, Constans L, Auguy F, Duhoux E. Choosing a reporter for gene expression studies in transgenic actinorhizal plants of the Casuarinaceae family. Plant Soil 2003; 254: 229-37. [http://dx.doi.org/10.1023/A:1024919400938]

[11] Yu AQ, Dong C, Li GL, Hu ZL. Molecular cloning, sequencing and analysis of chalcone synthase gene family based on Nelumbo nucifera (lotus) Submitted Key Lab of the Ministry of Education for Plant Developmental Biology. Wuhan, Hubei, China: College of Life Science, Wuhan University 2009.

[12] Murashige T, Skoog F. A revised medium for rapid growth and bioassays with tobacco tissue cultures. Physiol Plant 1962; 15 (3): 473-97. [http://dx.doi.org/10.1111/j.1399-3054.1962.tb08052.x]

[13] Doyle JJ, Doyle JL. A rapid DNA isolation procedure for small quantities of fresh leaf tissue. Phytochem Bull 1987; $19: 11-5$.

[14] Zhao D, Tao J, Han C, Ge J. Flower color diversity revealed by differential expression of flavonoid biosynthetic genes and flavonoid accumulation in herbaceous peony (Paeonia lactiflora Pall.). Mol Biol Rep 2012; 39(12): 11263-75. [http://dx.doi.org/10.1007/s11033-012-2036-7] [PMID: 23054003]

[15] Nakatsuka T, Nishihara M, Mishiba K, Yamamura S. Temporal expression of flovonoid biosynthesis-related genes regulates flower pigmentation in gentian plants. Plant Sci 2005; 168: 1309-18 [http://dx.doi.org/10.1016/j.plantsci.2005.01.009]

[16] Kozak D, Stelmaszczuk M. The effect of benzyladenine on shoot regeneration in vitro of Zantedeschia aethiopica 'green goddess'. Horticulture 2009; 19(1): 14-8.

[17] van West P, Reid B, Campbell TA, et al. Green fluorescent protein (GFP) as a reporter gene for the plant pathogenic oomycete Phytophthora palmivora. FEMS Microbiol Lett 1999; 178(1): 71-80. [http://dx.doi.org/10.1016/S0378-1097(99)00320-1] [PMID: 10483725]

[18] El-Shemy H, Khalafalla MM, Ishimoto M. The role of green fluorescent protein (GFP) in transgenic plant to reduce gene silencing phenomena. Curr Issues Mol Biol 2008; 11(Suppl. 1): 21-8.

[19] Dong C, Yu AQ, Wang ML, et al. Identification and characterization of chalcone synthase cDNAs (NnCHS) from Nelumbo nucifera. Cell Mol Biol (Noisy-le-grand) 2015; 61(8): 112-7. [PMID: 26718438]

[20] Kuvshinov V, Koivu K, Kanerva A, Pehu E. Agrobacterium tumefacience-mediated transformation of greenhouse-grown Brassica rapa ssp. Oleifera. Plant Cell Rep 1999; 18: 773-7. [http://dx.doi.org/10.1007/s002990050659]

[21] Saetiew K, Leethaweesup W, Parinthawong N, Arunyanart S. Transformation of antisense Dihydroflavonal 4- Reductase (DFR) into sacred lotus ‘Buntharik' using Agrobacterium-mediated gene transfer. Acta Hortic 2014; 1025: 99-106. [http://dx.doi.org/10.17660/ActaHortic.2014.1025.15]

C Kanjana et al.; Licensee Bentham Open

This is an open access article licensed under the terms of the Creative Commons Attribution-Non-Commercial 4.0 International Public License (CC BY-NC 4.0) (https://creativecommons.org/licenses/by-nc/4.0/legalcode), which permits unrestricted, non-commercial use, distribution and reproduction in any medium, provided the work is properly cited. 